\title{
Carnitine deficiency presenting with a decreased mental state in a patient with amyotrophic lateral sclerosis receiving long-term tube feeding: a case report
}

\author{
Naohi Isse ${ }^{1 *}$, Yoh Miura ${ }^{2}$, Toshiyuki Obata ${ }^{1}$ and Noriko Takahara ${ }^{1}$
}

\begin{abstract}
Introduction: L-carnitine is an important metabolic mediator involved in fatty acid transport. It is obtained from the diet, particularly from animal products, such as red meat. Previous reports have revealed that long-term tube feeding with a commercial product containing no or low levels of carnitine can lead to an altered mental state caused by hyperammonemia.

Case presentation: A 72-year-old Japanese man had a 12-year history of amyotrophic lateral sclerosis. He was bedridden and had required mechanical ventilation and enteral tube feeding for 10 years at home. His main enteral solution was a commercial product that contained low carnitine levels, and he sometimes received coffee and homemade products such as miso soup. Our patient's ability to communicate gradually deteriorated over a period of one year. His serum total carnitine level was abnormally low, at $26.7 \mu \mathrm{mol} / \mathrm{L}$ (normal range, 45 to $91 \mu \mathrm{mol} / \mathrm{L}$ ), but his ammonium level was normal. His mental state improved dramatically after starting L-carnitine supplementation (600mg twice daily).

Conclusion: This case highlights the importance of avoiding carnitine deficiency in patients with amyotrophic lateral sclerosis undergoing long-term tube feeding. These patients experience progressive muscle atrophy that might cause impaired carnitine storage and might manifest as communication difficulties. Carnitine deficiency can be misdiagnosed as a progression of systemic muscle atrophy. Clinicians should be aware of this disorder and should consider periodically measuring carnitine levels, regardless of the patient's serum ammonium levels.
\end{abstract}

Keywords: Amyotrophic lateral sclerosis, Carnitine deficiency, Communication, Mental state, Tube feeding

\section{Introduction}

L-carnitine is a natural constituent of higher organisms, including animal cells [1]. It is mainly obtained from dietary sources, particularly red meat and dairy products. Previous reports have revealed that long-term tube feeding with commercial products containing low or no carnitine can contribute to altered mental states caused by hyperammonemia [2]. Lack of carnitine causes the accumulation of unoxidized fatty acids, which inhibit the urea cycle, resulting in hyperammonemia. Adults with

\footnotetext{
* Correspondence: issenaohi@yahoo.co.jp

'Department of Internal Medicine, Ako City Hospital, 1090 Nakahiro,

Ako 678-0232, Hyogo, Japan

Full list of author information is available at the end of the article
}

chronic illnesses such as advanced cancer and chronic renal failure with hemodialysis are prone to carnitine deficiency because of decreased intake, increased utilization, or increased elimination of carnitine. Intravenous $\mathrm{L}$-carnitine treatment improved patient-assessed fatigue in patients undergoing hemodialysis [3]. However, L-carnitine supplementation to treat carnitine deficiency did not improve fatigue in patients with invasive malignancies and good performance status [4].

Amyotrophic lateral sclerosis (ALS) is a progressive neurodegenerative disease that results in severe muscle atrophy. There is no effective treatment, and patients with ALS usually require mechanical ventilation and longterm tube feeding. We describe the case of a patient with

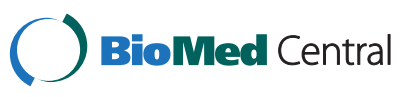

(c) 2013 Isse et al.; licensee BioMed Central Ltd. This is an open access article distributed under the terms of the Creative Commons Attribution License (http://creativecommons.org/licenses/by/2.0), which permits unrestricted use, distribution, and reproduction in any medium, provided the original work is properly cited. 
ALS who required long-term tube feeding and whose mental state deteriorated because of carnitine deficiency, despite normal ammonium levels.

\section{Case presentation}

A 72-year-old Japanese man had a 12-year history of ALS. He was bedridden and had been on mechanical ventilation and percutaneous endoscopic gastrostomy (PEG) tube feeding at home for the previous 10 years. He was fed $1000 \mathrm{~mL}(1000 \mathrm{kcal})$ of a commercial product (Ensure liquid ${ }^{\circ}$; Abbott Japan, Tokyo, Japan) containing $<1 \mathrm{nmol} / \mathrm{mL}$ of carnitine per day. He was also sometimes given homemade products such as miso soup and coffee with milk, all via the PEG tube. Over one year, his ability to communicate using facial expressions gradually deteriorated. He was still able to flex his left toe to control the communication device, but his energy appeared to diminish when attempting to focus on communication. He did not have muscle cramps, and his diabetes mellitus was well controlled with $25 \mathrm{mg}$ of alogliptin without renal insufficiency. His medical history included a colonic polyp, which was resected via endoscopy four years previously, and pneumothorax, which was treated conservatively one year previously. He had no history of rhabdomyolysis.

Laboratory evaluations performed to determine the cause of his altered mental state showed that his electrolytes, hematological parameters, including $\mathrm{HbA1c}$, and liver and renal function parameters were within normal ranges (Table 1). However, his serum total carnitine was abnormally low, at $26.7 \mu \mathrm{mol} / \mathrm{L}$ (normal range, 45 to $91 \mu \mathrm{mol} / \mathrm{L})$, as were his free carnitine $(20.6 \mu \mathrm{mol} / \mathrm{L}$; normal range, 36 to $74 \mu \mathrm{mol} / \mathrm{L}$ ) and acylcarnitine ester $(6.1 \mu \mathrm{mol} / \mathrm{L}$; normal range, 6 to $23 \mu \mathrm{mol} / \mathrm{L})$ levels. However, his ammonium level was normal $(48 \mu \mathrm{g} / \mathrm{dL}$; normal range, 12 to $68 \mu \mathrm{g} / \mathrm{dL})$.

Within two weeks of starting carnitine supplementation (600mg twice daily via the PEG tube), our patient's mental state improved to the level noted the previous year. His serum total carnitine recovered to $172.3 \mu \mathrm{mol} / \mathrm{L}$ (normal range, 45 to $91 \mu \mathrm{mol} / \mathrm{L}$ ) one year after starting carnitine supplementation. His free carnitine $(140.6 \mu \mathrm{mol} / \mathrm{L}$; normal range, 36 to $74 \mu \mathrm{mol} / \mathrm{L}$ ) and acylcarnitine ester $(31.7 \mu \mathrm{mol} / \mathrm{L}$; normal range, 6 to $23 \mu \mathrm{mol} / \mathrm{L})$ levels had also recovered at this time. Our patient's mental state has been maintained since starting carnitine supplementation.

\section{Discussion}

L-carnitine is found in a variety of food sources but is highly abundant in animal products. Ensure liquid ${ }^{\circ}$ is made from soybeans and casein, which are low in carnitine [5]. Our patient was given coffee with milk, but his total dietary carnitine intake appeared to be low. In healthy individuals, low carnitine intake does not always lead to carnitine deficiency because of abundant muscle stores, efficient reabsorption in the kidneys, and endogenous synthesis in the liver from lysine and methionine, which are present in sufficient amounts in Ensure liquid ${ }^{\circ}$. Normally, more than $95 \%$ of the body's total carnitine content would be stored in skeletal muscle [6,7]. However, in patients with ALS, severe muscle atrophy could reduce the carnitine stores, thus contributing to secondary carnitine deficiency caused by long-term enteral feeding with low-carnitine products.

Decreased plasma carnitine levels are an early marker of impending secondary carnitine deficiency in tissues. Low carnitine levels result in the accumulation of unoxidized fatty acids, causing hyperammonemia through inhibition of the urea cycle. Indeed, carnitine deficiency

Table 1 Laboratory tests (29 June 2012)

\begin{tabular}{llll}
\hline Parameter & Laboratory result & Parameter & Laboratory result \\
\hline White blood cells & $5800 / \mu \mathrm{L}$ & Total cholesterol & $157 \mathrm{mg} / \mathrm{dL}$ \\
Red blood cells & $419 \times 10^{4} / \mu \mathrm{L}$ & Triglyceride & $165 \mathrm{mg} / \mathrm{dL}$ \\
Hemoglobin & $12.3 \mathrm{~g} / \mathrm{dL}$ & High density lipoprotein cholesterol & $33 \mathrm{mg} / \mathrm{dL}$ \\
Platelets & $20.4 \times 10^{4} / \mu \mathrm{L}$ & Low density lipoprotein cholesterol & $100 \mathrm{mg} / \mathrm{dL}$ \\
Total protein & $7.2 \mathrm{~g} / \mathrm{dL}$ & Sodium & $142 \mathrm{mEq} / \mathrm{L}$ \\
Creatinine kinase & $22 \mathrm{U} / \mathrm{L}$ & Potassium & $3.7 \mathrm{mEg} / \mathrm{L}$ \\
Total bilirubin & $0.3 \mathrm{mg} / \mathrm{dL}$ & Chloride & $106 \mathrm{mEq} / \mathrm{L}$ \\
Aspartate transaminase & $17 \mathrm{U} / \mathrm{L}$ & Blood urea nitrogen & $21.9 \mathrm{mg} / \mathrm{dL}$ \\
Alanine transaminase & $10 \mathrm{U} / \mathrm{L}$ & Creatinine & $0.14 \mathrm{mg} / \mathrm{dL}$ \\
Lactate dehydrogenase & $145 \mathrm{U} / \mathrm{L}$ & Uric acid & $5.8 \mathrm{mg} / \mathrm{dL}$ \\
Gamma-glutamyl transpeptidase & $26 \mathrm{U} / \mathrm{L}$ & Blood glucose & HbA1c \\
Cholinesterase & $237 \mathrm{U} / \mathrm{L}$ & & $192 \mathrm{mg} / \mathrm{dL}$ \\
Amylase & $101 \mathrm{U} / \mathrm{L}$ & $5.8 \%$
\end{tabular}

${ }^{a}$ National Glycohemoglobin Standardization Program. 
has been reported in patients with hyperammonemia $[8,9]$. However, hyperammonemia was not seen in our patient. Anticonvulsants such as phenytoin and valproate $[5,8]$ and long-term administration of pivalate-containing antibiotics [10] have been reported to lower carnitine levels. Our patient did not take any drugs known to reduce carnitine levels.

Measuring plasma carnitine levels may help clinicians to differentiate between the progression of ALS and carnitine deficiency in patients with gradual impairments in communication, especially in patients receiving long-term tube feeding with commercial products. In transgenic mouse models with similar phenotypes to ALS in humans, muscle apoptosis was prevented by L-carnitine supplementation [11]. However, further research on L-carnitine supplementation is needed to confirm its role in preventing disease progression in patients with ALS.

\section{Conclusions}

Patients with ALS experience progressive muscle atrophy; therefore, it is inevitable that they will lose the ability to communicate over time. Many Japanese patients with ALS requiring PEG feeding are given nutritional products approved by the Ministry of Health, Labor and Welfare that are made from soybeans and casein, but frequently contain low levels of L-carnitine. To avoid gradual impairments in communication caused by secondary carnitine deficiency, clinicians should be aware of and regularly measure their patients' carnitine levels, regardless of their serum ammonia levels. If carnitine supplementation is necessary, it should be administered in the form of L-carnitine tablets or other products containing carnitine.

\section{Consent}

Written informed consent was obtained from the patient and his family for the publication of this case report. A copy of the written consent is available for review by the Editor-in-Chief of this journal.

\section{Abbreviations \\ ALS: Amyotrophic lateral sclerosis; PEG: Percutaneous endoscopic gastrostomy.}

\section{Competing interests}

The authors declare that they have no competing interests.

\section{Authors' contributions}

TO and NT analyzed and interpreted the patient's data regarding carnitine deficiency. YM was primarily responsible for the patient. NI was the lead writer of this manuscript. All authors read and approved the final manuscript.

\section{Acknowledgements}

We wish to thank Dr Mieko Ogino and Dr Eiji Kitamura in the Department of Neurology, Kitasato University School of Medicine, Japan, for their advice on ALS progression.

\section{Author details}

'Department of Internal Medicine, Ako City Hospital, 1090 Nakahiro, Ako 678-0232, Hyogo, Japan. ${ }^{2}$ Miura Clinic, 173-14 Daimochi, Kamigoori-cho, Ako-gun, Hyogo 678-1233, Japan.

Received: 20 November 2012 Accepted: 11 November 2013 Published: 30 December 2013

\section{References}

1. Rebouche CJ, Paulson DJ: Carnitine metabolism and function in humans. Ann Rev Nutr 1986, 6:41-66.

2. Ling $P$, Lee $D J$, Yoshida EM, Sirrs S: Carnitine deficiency presenting with encephalopathy and hyperammonemia in a patient receiving chronic enteral tube feeding: a case report. J Med Case Rep 2012, 6:227.

3. Brass EP, Adler S, Sietsema KE, Hiatt WR, Orlando AM, Amato A: Intravenous L-carnitine increases plasma carnitine, reduces fatigue, and may preserve exercise capacity in hemodialysis patients. Am J Kidney Dis 2001, 37(5):1018-1028.

4. Cruciani RA, Zhang JJ, Manola J, Cella D, Ansari B, Fisch MJ: L-carnitine supplementation for the management of fatigue in patients with cancer: an eastern cooperative oncology group phase Ш, randomized, doubleblind, placebo-controlled trial. J Clini Oncol 2012, 30(31):3864-3869.

5. Tanaka S, Miki T, Hsieh ST, Kim Jl, Yasumoto T, Taniguchi T, Ishikawa Y, Yokoyama M: A case of severe hyperlipidemia caused by long-term tube feedings. J Atheroscler Thromb 2003, 10(5):321-324.

6. Maeda K, Nakai S: Carnitine deficiency and nutritional measures. Jpn J Clin Dial 2001, 17(12):1597-1602.

7. Flanagan JL, Simmons PA, Vehige J, Willcox MD, Garrett Q: Role of carnitine in disease. Nutr Metab 2010, 7:30

8. Ohtani Y, Endo F, Matsuda I: Carnitine deficiency and hyperammonemia associated with valproic acid therapy. J Pediatr 1982, 101(5):782-785.

9. Limketkai BN, Zucker SD: Hyperammonemic encephalopathy caused by carnitine deficiency. J Gen Intern Med 2008, 23:210-213.

10. Nakajima Y, Ito T, Maeda Y, Ichiki S, Sugiyama N, Mizuno M, Makino Y, Sugiura T, Kurono $Y$, Togari H: Detection of pivaloylcarnitine in pediatric patients with hypocarnitinemia after long-term administration of pivalate-containing antibiotics. Tohoku J Exp Med 2010, 221:309-313.

11. Patel BP, Hamadeh MJ: Nutritional and exercise-based interventions in the treatment of amyotrophic lateral sclerosis. Clin Nutr 2009, 28(6):604-617.

\section{doi:10.1186/1752-1947-7-286}

Cite this article as: Isse et al:: Carnitine deficiency presenting with a decreased mental state in a patient with amyotrophic lateral sclerosis receiving long-term tube feeding: a case report. Journal of Medical Case Reports 2013 7:286.

\section{Submit your next manuscript to BioMed Central and take full advantage of:}

- Convenient online submission

- Thorough peer review

- No space constraints or color figure charges

- Immediate publication on acceptance

- Inclusion in PubMed, CAS, Scopus and Google Scholar

- Research which is freely available for redistribution 